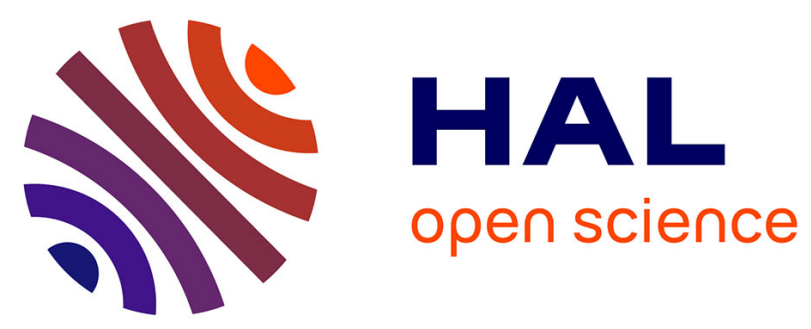

\title{
Atmospheric re-organization during Marine Isotope Stage 3 over the North American continent: sedimentological and mineralogical evidence from the Gulf of Mexico
}

T. Sionneau, V. Bout-Roumazeilles, G. Meunier, C. Kissel, B. P. Flower, A. Bory, N. Tribovillard

\section{To cite this version:}

T. Sionneau, V. Bout-Roumazeilles, G. Meunier, C. Kissel, B. P. Flower, et al.. Atmospheric reorganization during Marine Isotope Stage 3 over the North American continent: sedimentological and mineralogical evidence from the Gulf of Mexico. Quaternary Science Reviews, 2013, 81, pp.62-73. 10.1016/j.quascirev.2013.10.002 . hal-03210028

\section{HAL Id: hal-03210028 \\ https://hal.science/hal-03210028}

Submitted on 13 Jul 2021

HAL is a multi-disciplinary open access archive for the deposit and dissemination of scientific research documents, whether they are published or not. The documents may come from teaching and research institutions in France or abroad, or from public or private research centers.
L'archive ouverte pluridisciplinaire HAL, est destinée au dépôt et à la diffusion de documents scientifiques de niveau recherche, publiés ou non, émanant des établissements d'enseignement et de recherche français ou étrangers, des laboratoires publics ou privés. 


\title{
Atmospheric re-organization during Marine Isotope Stage 3 over the North American continent: sedimentological and mineralogical evidence from the Gulf of Mexico
}

T. Sionneau ${ }^{\text {a, }}$, V. Bout-Roumazeilles ${ }^{\text {a }}$, G. Meunier ${ }^{\text {a,b }}$, C. Kissel ${ }^{\text {c }}$, B.P. Flower ${ }^{\text {d }}$, A. Bory ${ }^{\text {a }}$, N. Tribovillard ${ }^{\mathrm{a}}$

${ }^{a}$ CNRS-UMR 8217 Géosystèmes, Université Lille 1, Bât. SN5, Cité Scientifique, 59655 Villeneuve d'Ascq Cedex, France

${ }^{\mathrm{b}}$ CNRS-UMR 6249, Laboratoire Chrono-Environnement, Université de Franche-Comté, 16 route de Gray, 25030 Besançon, France

${ }^{\mathrm{c}}$ Laboratoire des Sciences du Climat et de l'Environnement, 91198 Gif-sur-Yvette, France

${ }^{\mathrm{d}}$ College of Marine Science, University of South Florida, St. Petersburg, FL 33701, USA

* Corresponding author. Tel.: +33 (0)3 204343 95; fax: +33 (0)320434910.

E-mail address: sionneau.thomas@wanadoo.fr (T. Sionneau).

Keywords: Orca Basin - Mississippi River - Marine Isotope Stage 3 - Clay mineralogy Meltwater inputs - Paleoatmospheric configurations

\begin{abstract}
Mineralogical and sedimentological records from the Gulf of Mexico (GOM) reveal major changes in the terrigenous particles provenance during the Marine Isotopic Stage 3 (MIS3) that likely resulted from modifications of the environmental conditions - including glacial activity and precipitation distribution - over the North American continent. The south-eastern margin of the Laurentide Ice Sheet (LIS) was active throughout the entire MIS3, whereas the south-western margin contributed to short-term meltwater events only during late MIS3. Some of the major mineralogical changes cannot be attributed to glacial activity but rather result from the changes in precipitation distribution. Combining sedimentological records from the GOM with previously published climate-related archives from the North American continent allows the reconstruction of two main schematic patterns of moisture inflow and precipitation distribution that may have prevailed during MIS3. Meltwater discharges contribute to modifying the LIS configuration and the GOM hydrological properties, ultimately affecting large-scale oceanic circulation and may have influenced atmospheric reorganizations although the insolation variation rate appears to be the main driver of the system.
\end{abstract}




\section{Introduction}

Throughout the last decades, oxygen isotopic studies of Greenland ice cores (Dansgaard et al., 1982, 1993; Stuiver and Grootes, 2000) revealed important and rapid climatic fluctuations over the North Atlantic during the Marine Isotope Stage 3 (MIS3: 21-55 ka BP). Temperatures of Greenland air masses rose abruptly at the beginning of an interstadial ( $\delta^{18} \mathrm{O}$ maxima) and then decreased slowly to a minimum: a stadial ( $\delta^{18} \mathrm{O}$ minima). These millennial-scale climatic oscillations were called Dansgaard- Oeschger cycles. They could be applied to longer-duration cooling cycles called Bond cycles (Bond et al., 1993) with termination often characterized by the collapse of northern hemispheric ice sheets, generating large discharges of icebergs in the North Atlantic known as Heinrich events (Heinrich, 1988; Broecker et al., 1992), followed by a sudden shift from cold to warm temperatures.

Impacts of these climatic fluctuations have been identified in both marine and continental sites all over the world (Voelker et al., 2002). Although some regions may experience warmer and wetter conditions during interstadials compared with stadials (Clement and Peterson, 2008), temperatures as well as moisture availability and distribution displayed a pronounced regional heterogeneity. In the Gulf of Mexico (GOM), climatic conditions depend on the respective positions of the Inter-Tropical Convergence Zone, JetStream, Bermuda High and subtropical gyre (Forman et al., 1995; Liu and Fearn, 2000; Harrison et al., 2003; Knox, 2003). Grimm et al. (2006) suggested that climatic conditions over Florida were warm and wet during the coldest periods of Bond cycles, while cold and dry conditions were predominant in interior North America (Wang et al., 2003; Jacobs et al., 2007; Jiménez-Moreno et al., 2010). The conclusions of Grimm et al. (2006) are consistent with the hypothesis that decreased North Atlantic Deep Water formation, caused by the calving of icebergs into the North Atlantic during Heinrich events (Ganopolski and Rahmstorf, 2001), reduced the transport of heat from the GOM to northern high latitudes, leading to the warming of Florida.

Hill et al. (2006) reconstructed the oxygen isotopic composition of the northern GOM seawater during the MIS3 and demonstrated that meltwater pulses from the Laurentide Ice Sheet (LIS) occurred when temperatures over Greenland were cold, in contradiction with the previous theory which stipulated that "Dansgaard- Oeschger" warming corresponds to freshwater routing to the GOM (Clark et al., 2001). Understanding climatic and environmental conditions in the North America/GOM system during the MIS3 appears to be all the more difficult since continental evidence for the position of the LIS are 
very scarce due to glacial re-advance and erosion during the Last Glacial Maximum (Dyke et al., 2002).

Since the clay mineralogy of the potential main source areas in and around the Mississippi River watershed have been determined (Sionneau et al., 2008; Fig. 1a), clay mineral records of the northern continental slope of the GOM have provided valuable information on the provenance of freshwater inputs in the GOM during the last deglaciation (Montero-Serrano et al., 2009; Sionneau et al., 2010) and allowed reconstructions of atmospheric circulation shape and humidity transfer patterns over North America during the Holocene and Last Interglacial (Montero-Serrano et al., 2010, 2011).

In this article, we present sedimentological and mineralogical records of terrigenous sediments deposited during the MIS3 in the Orca Basin $\left(26^{\circ} 56.770 \mathrm{~N}, 91^{\circ} 20.740 \mathrm{~W}\right.$; northern GOM), which is considered to be an ideal site for high-resolution paleoclimatic studies (Flower et al., 2004; Hill et al., 2006; Sionneau et al., 2010), in order to determine a regional paleoatmospheric circulation model that could explain results of previous studies (Grimm et al., 2006; Hill et al., 2006).

\section{Geological settings}

Core MD02-2552 (26 $56.800 \mathrm{~N}, 91^{\circ} 20.72^{\prime} \mathrm{W}, 2250 \mathrm{~m}$ water depth) was recovered from the Orca Basin (Fig. 1b and c) during the IMAGES-PAGE cruise (Bout-Roumazeilles and Trentesaux, 2007) on board the R/V Marion Dufresne (IPEV) in 2002.

The Orca Basin is a small $(\sim 400 \mathrm{~km} 2)$, deep $(\sim 2400 \mathrm{~m})$ depression on the northern continental slope of the Gulf of Mexico (Shokes et al., 1977; Sheu, 1990; Tribovillard et al., 2008). It formed as a consequence of salt tectonics about $50 \mathrm{ka}$ ago. The depression is bordered by sills at $\sim 2000 \mathrm{~m}$ of depth, resulting in a shallow ( $<200-\mathrm{m}$-thick) restricted deep water mass. The contact between the bulk of the water mass, being of normal seawater chemistry, and the restricted deep-water mass occurs over a $50 \mathrm{~m}$ thick transition zone below $\sim 2200 \mathrm{~m}$. Across this contact, salinity increases from $35 \mathrm{ppt}$ to $\sim 260 \mathrm{ppt}$, density from 27 to $180\left(\sigma_{t}\right)$, dissolved oxygen falls to zero, and hydrogen sulfide rises to $>3 \mu \mathrm{M}$ (peaking at $\sim 2250 \mathrm{~m}$ ) before falling to zero in the deepest part of the water column. The exceptionally strong pycnocline limits exchange between the restricted deep water mass and the overlying water column. The high salinity of the deep water mass is maintained through dissolution of salt in shallow subsurface diapirs in the vicinity of the basin (Presley and Stearns, 1986; Sheu et al., 1987). 


\section{Clay mineralogical and sedimentological analysis}

The core MD02-2552 was sampled at 5-cm intervals from 19.5 to $30 \mathrm{~m}$ (covering $26.9 \mathrm{e} 45.3 \mathrm{ka})$. This interval was chosen in order to match the time interval studied by Hill et al. (2006) in core MD02-2551. A total of 206 samples were analyzed for clay mineralogy.

In this paper, "clay minerals" refer to the major phyllosilicate minerals within the claysize fraction (generally $<2 \mu \mathrm{m}$ ). They are identified by X-Ray Diffraction using the protocol explained in detail in published articles (Sionneau et al., 2008). The main northern American drainage basins contributing to GOM clay sedimentation are made up of four distinct mineralogical provinces (Sionneau et al., 2008; Table 1): (1) the smectite-rich northwestern Mississippi River watershed (55\% smectite on average), (2) the illite and chlorite-rich northeastern Mississippi River watershed and Great Lakes area (77\% illite plus chlorite on average), (3) the kaolinite-rich southeastern United States (58\% kaolinite on average) and (4) the illite and kaolinite-rich southwestern Mississippi River watershed (34\% illite and 23\% kaolinite on average). Considering that weathering/alteration processes on land are slow (Thiry, 2000), millennial-scale fluctuations of the clay mineralogy of GOM sedimentary deposits reflect changes of the respective contributions of the main mineralogical provinces (Sionneau et al., 2010).

Grain-size and magnetic susceptibility analyses were conducted using procedures detailed in published articles (Laj et al., 2000; Sionneau et al., 2010).

\section{Age model}

Cores MD02-2252 and MD02-2551 (26 56.78N, 91 $\left.{ }^{\circ} 20.75 \mathrm{~W}\right)$ are separated by only 62 $\mathrm{m}$ in the Orca Basin. Since these cores record rather similar sedimentological context, their correlation has been easily achieved using magnetic susceptibility (Fig. 2). Depth depth relationships between cores were established using the Macintosh AnalySeries- 1.2 software (Paillard et al., 1996). We used the published age model (Hill et al., 2006) of core MD022551 based on 17 AMS 14C dates from monospecific samples of pink G. ruber.

In order to test the stratigraphic control, we plotted on the age model three AMS 14C dates (determined at the Poznan Radiocarbon Laboratory - Poland) from the core MD022552, obtained from both G. ruber and mixed Globigerinoides sp. (G. ruber, G. sacculifer, G. trilobus) assemblages (Fig. 2). These three radiocarbon ages were calibrated to calendar years using the Fairbanks0107 online conversion program (Fairbanks et al., 2005). The 
chronostratigraphy was also constrained by the occurrence of a significant directional deviation associated to a low in relative intensity of the earth magnetic field between $26.75 \mathrm{~m}$ and $27.47 \mathrm{~m}$ in core MD02-2552 corresponding to the Laschamp geomagnetic excursion (Laj et al., 2000). We attributed the most recent and accurate coupled K/Ar, 40Ar/39Ar and $238 \mathrm{U} / 230 \mathrm{Th}$ dating of this excursion at $40,700 \pm 950 \mathrm{y} \mathrm{b} 2 \mathrm{k}$ (Singer et al., 2009) to the maximum directional deviation at $26.97 \mathrm{~m}$ in core MD02-2552. The date from G. ruber shells and the stratigraphic position of the Laschamp are in good agreement with the age model from MD02-2551. However the two dates determined from mixed Globigerinoides sp. are younger than ages extrapolated from the model age (1.8 and 1.1 cal ka younger for respectively 19.6 and $21.49 \mathrm{~m}$ depth in MD02-2552 core), probably because of the different nature of the shells used for dating (Aharon, 2003).

\section{Results: clay mineralogy and sedimentology}

The clay mineral fraction of the detrital sediments deposited in the Orca Basin during the MIS3 is mainly composed of illite $(\sim 57 \%)$, while smectite $(\sim 18 \%)$, chlorite $(\sim 13 \%)$ and kaolinite $(\sim 11 \%)$ contents are less important (Fig. 3). This average clay mineralogical composition is in agreement with previous studies, which demonstrated that glacial GOM sediments are enriched in illite and chlorite, compared with interglacial ones which are mainly composed of smectite (50-86\% of the clay association) during the Holocene and the last deglaciation (Montero-Serrano et al., 2010; Sionneau et al., 2010).

The clay mineral record in core MD02-2552 can be divided into four different time intervals (Fig. 3). Periods between 26.9 and $31.4 \mathrm{ka}$ and between 37.3 and $42.6 \mathrm{ka}$ are characterized by high illite (I) and chlorite (C) contents (I + C 75\%; Table 2). Smectite (S) and kaolinite $(\mathrm{K})$ are more abundant during the two other periods (31.4-37.3 ka and 42.6-45.3 ka). As a result, major and abrupt changes (at 31.4, 37.3 and $42.6 \mathrm{ka}$ ) of the $\mathrm{C} / \mathrm{K}$ and $\mathrm{S} /(\mathrm{I}+\mathrm{C}$ ) ratios highlight the transitions between these different intervals (Fig. 4).

Variations of the illite and chlorite contents seem correlated throughout the entire record. As this observation could result from the calculation method (a semi-quantitative approach using percentages), we calculated the correlation coefficient between illite and chlorite using their rough diffraction intensities (counts/second). The high correlation coefficient $\left(\mathrm{R}^{2}=0.74\right.$; number of samples $\left.=206\right)$ suggests that illite and chlorite are indeed linked to each other. This result points out a common origin for both minerals. In that frame, the northeastern province of the Mississippi River watershed and the Great Lakes area (I + C $=77 \%$; Table 1) appear to be the best candidate as a source of these two clay minerals since 
the southwestern province, an alternative source for illite, is poor in chlorite ( $+\mathrm{C}=39 \%$; Table 1). The changes in the clay mineral record are also related to the magnetic susceptibility values, which display similar variations than the $\mathrm{C} / \mathrm{K}$ ratio over the studied interval (Fig. $4 \mathrm{~b}$ ). Higher magnetic susceptibility is associated with illite and chlorite-rich intervals while very low values of magnetic susceptibility correspond to increased smectite and kaolinite contents (Fig. 3). This result suggests a common provenance for illite, chlorite and magnetic minerals, likely from the northeastern province (Kujau et al., 2010).

The smectite typically derives from the northwestern Mississippi River watershed area, whereas kaolinite may originate from both the southwestern province and/or from the kaolinite-rich southeastern province. As demonstrated by Sionneau et al. (2008), the clay mineral distribution in the northern GOM is mainly influenced by relative fluvial contribution (Mississippi River is the dominant source of terrigenous sediments whereas all other rivers inputs have more local influences) and by oceanic surface circulation (especially the Loop Current which is the dominant hydrologic feature of the GOM). Considering the sediment dispersal pattern in the GOM, kaolinite-rich suspended sediments from rivers of the southeastern United States are mostly transported southward over the Florida shelf and do not influence sedimentation on the Louisiana continental slope (Balsam and Beeson, 2003; Sionneau et al., 2008). This observation suggests that kaolinite recovered in the Orca Basin mainly derives from the southwestern province. Moreover, the kaolinite record shows a strong positive correlation with the $\mathrm{a}^{*}$ parameter of reflectance e reflecting the reddish color of the sediment e and with the first derivative at $570 \mathrm{~nm}$ (not shown) reflecting the hematite content (Balsam and Beeson, 2003). Kaolinite likely is derived from the red soils cropping out in the southwestern province of the Mississippi River watershed (Sionneau et al., 2008). Finally, kaolinite and smectite-rich intervals (31.4e37.3 ka and 42.6e45.3 ka) occurred during phase of low precipitation over Florida as suggested by pollen evidence (Grimm et al., 2006). This observation does not support an enhanced detrital supplies from the southeastern province at that time.

To summarize, as smectite (S) mainly comes from the northwestern Mississippi River watershed, illite and chlorite $(\mathrm{I}+\mathrm{C})$ from the northeastern Mississippi River watershed and the Great Lakes area and kaolinite $(\mathrm{K})$ from the southwestern mineralogical province, clay mineral ratio $\mathrm{S} /(\mathrm{I}+\mathrm{C})$ and $\mathrm{C} / \mathrm{K}$ may therefore document the main origin of the detrital supplies. The $\mathrm{S} /(\mathrm{I}+\mathrm{C})$ ratio indicates some variability within the smectite and kaolinite-rich intervals, which mainly results from varying smectite content as the $\mathrm{C} / \mathrm{K}$ ratio remains rather low and constant over these intervals (Fig. 4). 
The more recent glacial illite and chlorite-rich interval $(29.6-31.4 \mathrm{ka})$ is episodically interrupted by short-term smectite-rich episodes with smectite content up to $68 \%$ of the clay mineral fraction between 28.4 and $28.7 \mathrm{ka}$, at $29.1 \mathrm{ka}$ and between 29.8 and $30.5 \mathrm{ka}$ (Fig. 3). We interpreted these intervals as representing major detrital and freshwater discharges from the southwestern margin of the LIS similar to meltwater events observed during the last deglaciation (Montero-Serrano et al., 2009; Sionneau et al., 2010). The three short smectiterich events (28.4-28.7 ka, 29.1 ka and 29.8-30.5 ka; Fig. 3) appear to correlate with negative excursions of the $\delta^{18} \mathrm{O}_{\mathrm{SW}-\mathrm{GOM}}$ record documented in core MD02- 2551 (Hill et al., 2006).

The comparison between mean grain-size of detrital sediments deposited in the Orca Basin during the MIS3 and the clay mineralogical contents indicates a slightly finer mean grain-size $(\leq 8 \mu \mathrm{m})$ during the illite and chlorite-rich intervals whereas mean grain size is coarser $(\sim 9.5 \mu \mathrm{m})$ during smectite and kaolinite-rich intervals. Moreover, grain-size trends are similar to insoluble residue abundance documented in core MD02-2551 (not shown), which was interpreted as representing increased influx from the Mississippi River (Hill, 2006). Our results suggest that mean grain-size is slightly coarser as terrigenous flux increased. Grainsize is partly related to the hydrodynamical regime of the Mississippi River. Increased grainsize may thus indicate the erosion of the Mississippi River fluvial deposits caused by highenergy episodes that promoted the remobilization of coarser particles. The lack of clear correlation between the interval of enhanced Mississippi River influx observed between 31.4 and $37.3 \mathrm{ka}$ and meltwater pulses recorded by Hill et al. (2006) suggests that the coarsening of grain size may be related to erosional processes caused by increased

Overall mineralogical and sedimentological data indicate major and rapid modifications of the terrigenous supply within MIS3 (Table 2): detrital sedimentation results from a mixing between the illite and chlorite-rich northeastern province and Great Lakes area and the smectite-rich northwestern province between 26.9 and $31.4 \mathrm{ka}$ and between 37.3 and 42.6 ka whereas the main contributors appear to be the illite and kaolinite-rich southwestern and smectite-rich northwestern provinces between 31.4 and $37.3 \mathrm{ka}$ and between 42.6 and $45.3 \mathrm{ka}$ (Fig. 5). Although the supplies from the northwestern and northeastern provinces may be linked to variable glacial activity along the southern margin of the LIS (i.e. phases of retreat/growth, proglacial lakes, activity of glacial lobes; Sionneau et al., 2008, 2010; Montero-Serrano et al., 2010) the supply of kaolinite from the southwestern province may only be explained by enhanced precipitation over this area. Such changes 
imply strong modifications of environmental conditions over the North American continent during MIS3.

\section{Discussion: glacial activity of the LIS and moisture transfers from the GOM during MIS3}

The clay and sedimentological records from the Orca Basin were compared with previously published paleo-environmental records including the Mississippi River discharge intensity (Hill, 2006) and lower Mississippi terrace levels (Rittenour et al., 2005), loess and paleosoil deposition (Forman et al., 1992; Johnson et al., 2007; Wang et al., 2009; Pierce et al., 2011), lacustrine records (Jacobs et al., 2007; Wood et al., 2010), braided vs. meandering river systems in the Atlantic coastal plains (Leigh et al., 2004), pollen association and vegetation (Fredlund, 1995; Baker et al., 2009; Pierce et al., 2011) and summer precipitation over Florida (Grimm et al., 2006; Donders et al., 2011). When we compare data from different cores recovered in the Gulf of Mexico and various continental archives, however, it is important to keep in mind that all records have independent age models which all contain uncertainties. The continental records have been dated using radiocarbon ages, optically stimulated luminescence (OSL) or thermoluminescence (TL) techniques leading to rather different age uncertainties. OSL dating is generally more accurate for recent studies due to technological development, but the overall uncertainty is _5\%. The range of age estimate for TL dating, including the error, is larger than for radiocarbon dating. Nevertheless, thanks to the use of mixed dating techniques, the comparison between continental and marine records including the TL and OSL age uncertainties is still meaningful (Fig. S-1) although the phasing between records may be somehow imprecise. Additional information on the chronological frame of these records (dates and error) is given in Fig. S-1. The comparison of these records allows the identification of the distribution of the main wet/arid areas over the Mississippi River watershed as well as the identification of the LIS areas displaying glacial activity during MIS3.

Our results were also compared with the oxygen isotopic composition of northern GOM surface waters (Hill et al., 2006; Flower et al., 2011) and the mean summer insolation at $30^{\circ}$ and $45^{\circ} \mathrm{N}$ (Fig. 4) in order to propose moisture transfer patterns and glacial activity of the LIS that may be consistent with both continental and marine evidences (Fig. 6). The resulting hypotheses on precipitation, moisture transfer 
and wind distributions during MIS3 were compared with global climate simulations for the MIS3 (Van Meerbeeck et al., 2009) and with regional climate simulations for summer during the LGM (Bromwich et al., 2005) in order to test their consistency.

\section{1. (I ? C)-rich intervals (29.6e31.4 $\mathrm{ka}$ and 37.3e42.6 $\mathrm{ka}$ )}

The sedimentary record from the GOM indicates that the detrital fraction mainly derives from the northeastern province encompassing the Great Lakes area during these two time intervals. The various environmental records provide heterogeneous evidence of wet or dry conditions over North America, reflecting regional or global climate. The deposition of the loess in Illinois (Roxana silt formation) and in Iowa (Pisgah formation), linked to arid climatic conditions and to the exposure of glacially-derived sediments (Forman et al., 1992; Wang et al., 2009), indicates that arid and glacial processes were dominant features throughout the whole MIS3 although records of glacial activity are very scarce on the southeastern margin of the LIS, likely obliterated by the LGM maximum glacial advance.

On the other hand, there are several pieces of evidence (Fig. 6a) that precipitation may have been abundant on the northeastern and southeastern provinces over these illite and chlorite-rich periods, including: (1) the development of braiding on the Atlantic Coastal margin (Leigh et al., 2004); (2) the elevation of the downstream southern lower Mississippi River Valley terraces (Rittenour et al., 2005) reflecting flooding episodes; and (3) the development of wet conditions in Florida (Grimm et al., 2006; Donders et al., 2011). Wetter conditions over the southeastern province do not induce an increased supply of kaolinite-rich sediments toward the Orca Basin since detrital supplies from this province are distributed southward on the Florida shelf as a result of the main sediment dispersal patterns forced by oceanic circulation (Balsam and Beeson, 2003; Sionneau et al., 2008). Similar regional differences in precipitation during MIS3 were also evident in a recent review of vegetation records (Jiménez-Moreno et al., 2010).

As indicated by the short smectite-rich intervals in the mineralogical record, the most recent illite and chlorite-rich interval (29.6-31.4 ka) is marked by two meltwater episodes originating from the northwestern province, suggesting glacial advance of the Des Moines and James glacial lobes in the late MIS3-early MIS2 (Fig. 6b), similar with events punctuating the last deglaciation (Montero-Serrano et al., 2009; Sionneau et al., 2010). 
In summary, the illite and chlorite-rich periods correspond to an enhanced glacial activity of the southeastern LIS margin with short-term episodic contributions from the southwestern margin in the most recent part of the record, which is consistent with the reconstructed LIS margin for MIS3 (Dyke et al., 2002; Van Meerbeeck et al., 2009). During these periods, precipitation occurred mainly along the eastern part of the North American continent, while the southwestern and northwestern provinces experienced dry conditions, pointing out that the general moisture pattern was somehow similar with present-day winter situations. Such a configuration suggests that the Polar Jet Stream was blocked below 40_N on its western side while located above 40_N on eastern side, displaying a dominant meridional component, preventing moisture inflow from the GOM toward the western Mississippi River watershed while promoting precipitation on the Atlantic margin (Fig. 6a and b). Meanwhile the Bermuda High was likely not in its westward position, in order to promote the convergence of air masses and the associated precipitation belt both in Florida and along the Atlantic coast.

\section{2. ( $\mathrm{K}$ ? S)-rich intervals (31.4e37.3 and $42.6 e 45.3 \mathrm{ka}$ )}

These two periods are marked by an increased detrital supply originating from the western provinces both north and south, suggesting a westward position of moisture inflow from the GOM and a southwestern position of the associated precipitation belt (Figs. 3, 4, 6c and 6d). Pollen and vegetation records from Kansas and Nebraska support the development of wet conditions over the western provinces (Fredlund, 1995; Johnson et al., 2007; Baker et al., 2009). Meanwhile, the Roxana loess deposition demonstrates the persistence of cold and arid conditions in Illinois (Forman et al., 1992) suggesting that the Jet Stream was likely located below $45^{\circ} \mathrm{N}$, somewhere in between the north and the southwestern provinces, with a dominant zonal component (Fig. 6c). The shift from meandered to braided river system after 30 ka suggests reduced precipitations over the Atlantic Coastal margin (Leigh et al., 2004) at least during the last kaolinite and smectite-rich period (31.4-37.3 ka). This theory is supported by the development of glacial activity on the northeastern province (Wood et al., 2010) and by the drier climatic conditions over Florida (Grimm et al., 2006; Donders et al., 2011). The occurrence of dry climatic conditions along the Atlantic margin points out a westward migration of the Bermuda High, favoring the displacement of the main moisture flux toward the central interior (Fig. 6c). 
The recurrent occurrence of smectite during this interval - which does not match the main meltwater events as recorded by the $\delta^{18} \mathrm{O}_{\mathrm{sw}}$ (Hill et al., 2006; Flower et al., 2011) - suggests episodic intrusion of the southerly moisture flux and associated precipitation belt over the northwestern province (Fig. 6d). Recent climate model simulations suggest that humid and warm air masses, promoting enhanced precipitation over the northwestern province, originated from the GOM. Humidity generated over the Pacific Ocean was confined over the western coasts of the United States during the MIS3 (Van Meerbeeck et al., 2009). The development of episodic wet periods interrupting generally arid conditions over the northwestern province is also consistent with episodic paleosoils development interbedded in the Roxana Silt Formation in the central lowland and Great Plains area (Wang et al., 2009; Pierce et al., 2011). Moreover the specific mean grain-size $(<10 \mu \mathrm{m})$ characterizing sediment deposited during this interval correspond to sortable silt sized particles and supports the hypothesis of the sediments being reworked from loess formations such as the Roxana silt during episodic precipitations.

In summary, these kaolinite and smectite-rich intervals reflect the westward migration of the southerly flow from the GOM, promoting the development of moist conditions over the southwestern province while the southeastern province experienced dry conditions. The sedimentological data indicate that the moisture flow may have episodically penetrated northward during summer promoting precipitation on the northwestern province.

Knox (2000) shown that Mississippi River paleoflood intensity, during the Holocene, increased significantly when humid and warm air masses from the GOM circulated toward the northern Mississippi River watershed. Bromwich et al. (2005) demonstrated with modeling studies that episodic summer precipitation occurred along the LIS margin during the last glaciation as the inflow of moisture from the GOM encountered the cold katabatic winds from the ice-sheet. This simulation also indicates that the distribution of precipitation was likely affected by minor changes in large-scale circulation, whose variability may explain the alternation of wet/ dry conditions over the northwestern province (Bromwich et al., 2005).

MIS3 global climate simulation did not e so far e reconstruct episodic penetration of humid and warm air-masses from the GOM toward interior North America. Nevertheless, considering that MIS3 climate conditions are somehow complex and hard 
to disentangle (oscillating from cold stadials to warm interstadials with contrasting extension of the LIS) we postulated that MIS3 climate conditions may be intermediate between the one simulated for the Holocene and LGM (Van Meerbeeck et al., 2009; Brandefelt et al., 2011). Thus the simulated annual precipitation amount is substantially higher in MIS3 model than in LGM model with a significant increase over the Great Lakes area and eastern coasts of North America, while it was lower, however, over the US plains (Van Meerbeeck et al., 2009; Brandefelt et al., 2011). As a whole, climate simulations of MIS3 evidencing enhanced precipitation over the eastern coasts of North America are partly in agreement with our data. Our records not only allow identification of general trends during MIS3 but also rather provide detailed and subtle variations of precipitation distribution that models simulation did not yet allow obtaining in routine. In that frame, our mineralogical dataset from the Orca Basin is globally consistent with results of these climate simulations for the illite and chlorite-rich periods. But climate simulations did not - so far - successfully reproduce the observed enhanced detrital contribution from the northwestern during the smectite and kaolinite-rich intervals. In that sense, our data, which give information about the continental erosion driven by precipitation distribution and/or glacial processes over the North American continent during the MIS3, provide additional and precise constrains for further simulation of MIS3 climate.

\subsection{Relation between meltwater events and insolation}

The $\delta^{18} \mathrm{O}_{\text {sw }}$ from the Orca Basin shows six major meltwater events between 28.5 and $30 \mathrm{ka}$, between 31.3 and $34 \mathrm{ka}$, around $35 \mathrm{ka}$, between 37.2 and $39.6 \mathrm{ka}$, between 42.8 and $44 \mathrm{ka}$ and between 44.5 and $43.3 \mathrm{ka}$ (Hill et al., 2006; Flower et al., 2011). The main meltwater events recorded in the Gulf of Mexico are not associated with similar modifications of the terrigenous signal (Fig. 4). The sedimentological and mineralogical records of the meltwater discharges F1 and F6 are comparable to the signature of the main deglacial meltwater event (14.1-14.6 cal ka) characterizing the last deglaciation suggesting destabilization of glacial lobes along the southwestern margin of the LIS (Montero-Serrano et al., 2009; Sionneau et al., 2010). By contrast, the two main meltwater events F2 and F4 are not characterized by any change of the clay association. However, they are contemporaneous with two important phases of the lower Mississippi River terraces (Rittenour et al., 2005) suggesting enhanced detrital supply 
but constant provenance. The mismatch between the mineralogical record and the meltwater pulses as recorded by the $\delta^{18} 0$ measured on foraminifera is crucial since it indicates that some variations of the detrital provenance during MIS3 were not controlled by meltwater floods although it has been shown to be the case during last deglaciation (Sionneau et al., 2010). In that frame, some of mineralogical variations observed in the Orca Basin rather record changes in precipitation patters over the North American continent.

In our study, the main meltwater pulses appear to precede the clay mineralogical transitions that characterize atmospheric reorganizations above the GOM and the North American continent. Meltwater floods F2 and F5 occurred just before eastward shifts of the main precipitation belt at 31.4 and 42.6 ka respectively, while the migration of the precipitation belt from the Atlantic Coastal margin to the western Mississippi River and Rio Grande River watersheds at $37.3 \mathrm{ka}$. This suggests that the meltwater discharges may be one part of the chain of events that triggered the atmospheric re-organization revealed by our sedimentological records. This relationship between the meltwater inputs and seasonality in the North Atlantic Ocean was investigated by Flower et al. (2011) which proposed the "meltwater capacitor" hypothesis made of four components: (1) increase summer insolation, (2) ice-sheet meltwater inputs, which (3) inhibits winter deep convection in the northern North Atlantic and reduces Atlantic Meridional Overturning Circulation (AMOC), and (4) increased continentality - due to expanded winter sea ice -promoting hypercold winters.

The timing of the atmospheric circulation re-organization over North America as evidenced by our results suggests the influence of insolation variations. Indeed, surface conditions in the GOM have been shown to be mainly controlled by low-latitude summer insolation while being insensitive to winter conditions (Ziegler et al., 2008). Climate simulations for MIS3 evidence that orbital insolation forcing leads to enhanced northern hemisphere seasonality, with warm summers resulting from increase summer insolation, whereas winter insolation did not change substantially (Van Meerbeeck et al., 2009; Brandefelt et al., 2011). Enhanced seasonality was proposed to explain the simultaneous occurrence of dry conditions at Lake Petén Itza in Central America (Hodell et al., 2008), a southward position of the ITCZ, warm and moist conditions in Florida (Grimm et al., 2006) during the coldest periods of the MIS3, while the North Atlantic Ocean was experiencing cold sea-surface conditions and reduced AMOC. 
Although the variations of summer insolation during MIS3 appear too slow compared with the occurrence of melting events, they are consistent with the timing of the main modifications of atmospheric configurations: the westward migration of the precipitation belt occurred when the insolation change rates at $45_{-}$and $30 \_\mathrm{N}$ were at a maximum and when the difference in interhemispheric insolation was at its minimum (37.3 ka), whereas the shift back to its eastern position coincides with lower rates of summer insolation change ( 31.4 and $42.6 \mathrm{ka}$ ), when the differences between northern and southern insolation were at a maximum (Fig. 4). Nürnberg et al. (2008) pointed out a strengthened, northward flowing Loop Current in line with the northward position of the Inter-tropical Convergence Zone when insolation became more important in the northern hemisphere than in the southern hemisphere (i.e. after $37.3 \mathrm{ka}$ ), allowing northeastern Gulf of Mexico surface hydrographic conditions to approach those of the Caribbean. The increase of GOM sea surface temperatures would enhance evaporation in the northern GOM, which would promote the intensification of the humidity transfers toward the North American continent, the strengthening precipitations over the northwestern province and the supply of smectite rich detrital sediments transported by the Mississippi River.

\section{Concluding remarks}

The GOM clay mineral and sedimentological signals from Orca Basin core MD022552 allow determination of the geographical sectors of the LIS contributing to the major meltwater events as recorded in the $\delta^{18} \mathrm{O}_{\mathrm{SW}}$ during MIS3. The southeastern margin is active throughout MIS3, while the southwestern margin contributed to the short-term massive discharge around 29 ka (based on $\delta^{18} \mathrm{O}_{\mathrm{sw}}$ records) similar to the major meltwater events that punctuated the last deglaciation. Major changes of the clay mineral association e at $31.4,37.3$ and $42.6 \mathrm{ka}$ e reflect modifications of the respective western and northeastern province contributions, which cannot be attributed to glacial activity but rather result from changing precipitation distribution.

Combining sedimentological records from the GOM with previously published climate-related archives from the North American continent lead us to propose two main schematic patterns of moisture inflow and precipitation distribution that prevailed during MIS3. A dominant meridional component of the Polar Jet Stream associated with an eastward position of the Bermuda High provided precipitation along the Atlantic 
Coastal margin while a zonal Jet Stream and a westward Bermuda High promoted rainfall over the western Mississippi River drainage basin provinces. This last pattern is characterized by episodic northward penetration of the moisture flow, shown by the alternation of wet/dry sequences in the northwestern province, which may be due to minor changes in large-scale circulation as suggested by regional climate simulations. The main atmospheric re-organizations, occurring after the largest and longest meltwater events, are consistent with insolation variations, being synchronous with extreme summer insolation differences between the north and south hemispheres. Meltwater discharge, which may have modified the LIS configuration and the GOM hydrological properties and ultimately affected the large-scale circulation, likely played a role in triggering atmospheric reorganization by crossing a threshold, although the insolation variation rate appears to be the main driver of the system.

\section{Acknowledgments}

This work is dedicated to the memory of our friend and colleague Ben Flower who passed away too early. We thank the IMAGES (International Marine Past Global Change Study) program and the IPEV (Institut Polaire Français, Paul-Emile Victor) for a memorable cruise in the Gulf of Mexico on the R/V Marion Dufresne in 2002. TS is very grateful to A. Hood for English improvements. This study was financially supported by the UMR Geosystemes of the University of Lille 1 (France). The authors thank the editor Henning A. Bauch and the two anonymous reviewers for their helpful and constructive comments which greatly improved this manuscript.

\section{References}

Aharon, P., 2003. Meltwater flooding events in the Gulf of Mexico revisited: Implications for rapid climate changes during the last deglaciation. Paleoceanography 18, 1079. http://dx.doi.org/10.1029/2002PA000840.

Baker, R.G., Bettis III, E.A., Mandel, R.D., Dorale, J.A., Fredlund, G.G., 2009. MidWisconsinan environments on the eastern Great Plains. Quat. Sci. Rev. 28, 873-889.

Balsam, W.L., Beeson, J.P., 2003. Sea-floor sediment distribution in the Gulf of Mexico. Deep Sea Res. 50, 1421e1444. 
Bond, G., Broecker, W., Johnsen, S., McManus, J., Labeyrie, L., Jouzel, J., Bonani, G., 1993. Correlations between climate records from North Atlantic sediments and Greenland ice. Nature 365, 143-147.

Bout-Roumazeilles, V., Trentesaux, A., 2007. Sedimentologic analysis of cores, recovered from the RV Marion Dufresne cruise in the Gulf of Mexico, 2-18 July, 2002 (Chapter 5). In: Winters, W.J., Lorenson, T.D., Paull, C.K. (Eds.), Initial Report of the IMAGES VIII/PAGE 127 Gas Hydrate and Paleoclimate Cruise on the R/V Marion Dufresne in the Gulf of Mexico, 2-18 July 2002. U.S. Geological Survey Open-File Report 2004-1358 Online.

Brandefelt, J., Kjellström, E., Näslund, J.-O., Strandberg, G., Voelker, A.H.L., Wohlfarth, B., 2011. A coupled climate model simulation of Marine Isotope Stage 3 stadial climate. Clim. Past 7, 649-670.

Broecker,W.S., Bond, G., Klas, M., Clark, E., McManus, J., 1992. Origin of the northern Atlantic's Heinrich events. Clim. Dyn. 1992, 265-273.

Bromwich, D.H., Toracinta, E.R., Oglesby, R.J., Fastook, J.L., Hughes, T.J., 2005. LGM summer climate on the southwestern margin of the Laurentide Ice Sheet: wet or dry? J. Clim. 18, 3317-3338.

Clark, P.U., Marshall, S.J., Clarke, G.K.C., Hostetler, S.W., Licciardi, J.M., Teller, J.T., 2001. Freshwater forcing of abrupt climate change during the last glaciation.

Science 293, 283-287.

Clement, A.C., Peterson, L.C., 2008. Mechanisms of abrupt climate change of the last glacial period. Rev. Geophys. 46, RG4002. http://dx.doi.org/10.1029/2006RG000204.

Dansgaard, W., Clausen, H.B., Gundestrup, N., Hammer, C.U., Johnsen, S.F., Kristinsdottir, P.M., Reeh, N., 1982. A New Greenland deep ice core. Science 218, 1273-1277.

Dansgaard, W., Johnsen, S.J., Clausen, H.B., Dahl-Jensen, D., Gundestrup, N.S., Hammer, C.U., Hvidberg, C.S., Steffensen, J.P., Sveinbjörnsdottir, A.E., Jouzel, J., Bond, G., 1993. Evidence for general instability of past climate from 250-kyr ice core record. Nature 364, 218-220.

Donders, T.H., de Boer, H.J., Finsinger, W., Grimm, E.C., Dekker, S.C., Reichart, G.J., Wagner-Cremer, F., 2011. Impact of the Atlantic Warm Pool on precipitation and temperature in Florida during North Atlantic cold spells. Clim. Dyn. 36, 109- 118. 
Dyke, A.S., Andrews, J.T., Clark, P.U., England, J.H., Miller, G.H., Shaw, J., Veillette, J.J., 2002. The Laurentide and Innuitian ice sheets during the Last Glacial Maximum. Quat. Sci. Rev. 21, 9-31.

Fairbanks, R.G., Mortlock, R.A., Chiu, T.-C., Cao, L., Kaplan, A., Guilderson, T.P., Fairbanks, T.W., Bloom, A.L., Grootes, P.M., Nadeau, M.-J., 2005. Radiocarbon calibration curve spanning 0 to 50,000 years $\mathrm{BP}$ based on paired $230 \mathrm{TH} / 234 \mathrm{U} / 238 \mathrm{U}$ and $14 \mathrm{C}$ dates on pristine corals. Quat. Sci. Rev. 24, 1781-1796.

Flower, B.P., Hasting, D.W., Hill, H.W., Quinn, T.M., 2004. Phasing of deglacial warming and Laurentide Ice Sheet meltwater in the Gulf of Mexico. Geology 32, 597-600.

Flower, B.P., Williams, C., Hill, H.W., Hastings, D.W., 2011. Laurentide Ice Sheet Meltwater and the Atlantic Meridional Overturning Circulation during the Last Glacial Cycle: a View from the Gulf of Mexico. In: Geophysical Monograph Series, vol. 193, pp. $39-56$.

Forman, S.L., Bettis III, E.A., Kemmis, T.J., Miller, B.B., 1992. Chronological evidence for multiples periods of loess deposition during the Late Pleistocene in the Missouri and Mississippi River Valley, United States: implication for the activity of the Laurentide Ice Sheet. Palaeogeogr. Palaeoclimatol. Palaeoecol. 93, 71-83.

Forman, S.L., Oglesby, R., Markgraf, V., Stafford, T., 1995. Paleoclimatic significance of late Quaternary eolian deposition on the Piedmont and High Plains, central United States. Global Planet. Change 11, 35-54.

Fredlund, G.G., 1995. Late Quaternary pollen record from Cheyenne Bottoms, Kansas. Quat. Res. 43, 67-79.

Ganopolski, A., Rahmstorf, S., 2001. Rapid changes of glacial climate simulated in a coupled climate model. Nature 409, 153-158.

Grimm, E.C., Watts, W.A., Jacobson Jr., G.L., Hansen, B.C.S., Almquist, H.R., DieffenbacherKrall, A.C., 2006. Evidence for warm wet Heinrich events in Florida. Quat. Sci. Rev. 25, 2197-2211.

Harrison, S.P., Kutzbach, J.E., Liu, Z., Bartlein, P.J., Otto-Biesner, B., Muhs, D., Prentice, I.C., Thompson, R.S., 2003. Mid-Holocene climates of the Americas: a dynamical response to changed seasonality. Clim. Dyn. 20, 663-688.

Heinrich, H., 1988. Origin and consequences of cyclic ice rafting in the Northeast Atlantic Ocean during the past 130,000 years. Quat. Res. 29, 142-152. 
Hill, H.W., 2006. Abrupt Climate Change during the Last Glacial Period: a Gulf of Mexico Perspective (Theses and dissertations). Paper 2558 http:// scholarcommons.usf.edu/etd/2558.

Hill, H.W., Flower, B.P., Quinn, T.M., Hollander, D.J., Guilderson, T.P., 2006. Laurentide Ice Sheet meltwater and abrupt climate change during the last glaciation. Paleoceanography 21, PA1006. http://dx.doi.org/10.1029/2005PA001186.

Hodell, D.A., Anselmetti, F.S., Ariztegui, D., Brenner, M., Curtis, J.H., Gilli, A., Grzesik, D.A., Guilderson, T.J., Müller, A.D., Bush, M.B., Correa-Metrio, A., Escobar, J., Kutterolf, S., 2008. An 85-ka record of climate change in lowland Central America. Quat. Sci. Rev. 27, 11521165.

Jacobs, K.C., Fritz, S.C., Swinehart, J.B., 2007. Lacustrine evidence for moisture changes in the Nebraska Sand Hills during Marine Isotope Stage 3. Quat. Res. 67, 246-254.

Jiménez-Moreno, G., Anderson, R.S., Desprat, S., Grigg, L.D., Grimm, E.C., Heusser, L.E., Jacobs, B.F., López-Martínez, C., Whitlock, C.L., Willard, D.A., 2010. Millennial-scale variability during the last glacial in vegetation records from North America. Quat. Sci. Rev. 29, 2865-2881.

Johnson, W.C., Willey, K.L., Mason, J.A., May, D.W., 2007. Stratigraphy and environmental reconstruction at the middle Wisconsinan Gilman Canyon formation type locality, Buzzard's Roost, southwestern Nebraska, USA. Quat. Res. 67, 474-486.

Knox, J.C., 2000. Sensitivity of modern and Holocene floods to climate change. Quat. Sci. Rev. 19, 439-457.

Knox, J.C., 2003. North American palaeofloods and future floods: responses to climate change. In: Gregory, K.J., Benito, G. (Eds.), Palaeohydrology: Understanding Global Change. J. Wiley and Sons, Chichester, pp. 143-164.

Kujau, A., Nürnberg, D., Zielhofer, C., Bahr, A., Röhl, U., 2010. Mississippi River discharge over the last w560,000 years e indications from X-ray fluorescence core-scanning. Palaeogeogr. Palaeoclimatol. Palaeoecol. 298, 311-318.

Kutzbach, J.E., Wright, H.E., 1985. Simulation of the climate of 18,000 yr BP: results for the North American/North Atlantic/European sector and comparison with the geologic records. Quat. Sci. Rev. 4, 147-187.

Laj, C., Kissel, C., Mazaud, A., Channell, J.E.T., Beer, J., 2000. North Atlantic paleointensity stack since 75 ka (NAPIS-75) and the duration of the Laschamp event. Philos. Trans. R. Soc. London Ser. A 358, 1009-1025. 
Leigh, D.S., Srivastava, P., Brook, G.A., 2004. Late Pleistocene braided rivers of the Atlantic Coastal Plain, USA. Quat. Sci. Rev. 23, 65-84.

Liu, K.B., Fearn, M., 2000. Reconstruction of prehistoric landfall frequencies of catastrophic hurricanes in Northwestern Florida from lake sediment records. Quat. Res. 54, 238-245.

Montero-Serrano, J.C., Bout-Roumazeilles, V., Tribovillard, N., Sionneau, T., Riboulleau, A., Bory, A., Flower, B.P., 2009. Sedimentary evidence of deglacial megafloods in northern Gulf of Mexico (Pigmy Basin). Quat. Sci. Rev. 28, 3333-3347.

Montero-Serrano, J.C., Bout-Roumazeilles, V., Sionneau, T., Tribovillard, N., Bory, A., Flower, B.P., Riboulleau, A., Martinez, P., Billy, I., 2010. Changes in precipitation regimes over North America during the Holocene as recorded by mineralogy and geochemistry of Gulf of Mexico sediments. Global Planet. Change 74, 132-143.

Montero-Serrano, J.C., Bout-Roumazeilles, V., Carlson, A.E., Tribovillard, N., Bory, A., Meunier, G., Sionneau, T., Flower, B.P., Martinez, P., Billy, I., Riboulleau, A., 2011. Contrasting rainfall patterns over North America during Holocene and Last Interglacial as recorded by sediments of the northern Gulf of Mexico. Geophys. Res. Lett. 38, L14709. http://dx.doi.org/10.1029/2011GL048194.

Nürnberg, D., Ziegler, M., Karas, C., Tiedemann, R., Schmidt, M., 2008. Interacting Loop Current variability and Mississippi River discharge over the past 400 kyrs. Earth Planet. Sci. Lett. 272, 278-289.

Paillard, D., Labeyrie, L., Yiou, P., 1996. Macintosh program performs time-series analysis. Eos Trans. Am. Geophys. Union 77, 379.

Pierce, K.L., Muhs, D.R., Fosberg, M.A., Mahan, S.A., Rosenbaum, J.G., Licciardi, J.M., Pavich, M.J., 2011. A loess-paleosol record of climate and glacial history over the past two glacial interglacial cycles (150 ka), southern Jackson Hole, Wyoming. Quat. Res. 76, 119-141.

Presley, B.J., Stearns, S., 1986. Interstitial water chemistry, Deep Sea Drilling Project Leg 961. In: Bouma, A.H., Coleman, J.M., Meyer, A.W., et al. (Eds.), Init. Repts. DSDP, 96. U.S. Govt. Printing Office, Washington, pp. 697-709.

Rittenour, T.M., Goble, R.J., Blum, M.D., 2005. Development of an OSL chronology for Late Pleistocene channel belts in the lower Mississippi valley, USA. Quat. Sci. Rev. 24, 25392554.

Sheu, D.-D., 1990. The anoxic Orca Basin (Gulf of Mexico): geochemistry of brines and sediments. Rev. Aquat. Sci. 2, 491-507. 
Sheu, D.-D., Shakur, A., Pigott, J.D., Wiesenburg, D.A., Brooks, J.M., Krouse, H.R., 1987. Sulfur and oxygen isotopic compositions of dissolved sulfate in the Orca Basin: implications for origin of the high-salinity brine and oxidation of sulfides at the brine seawater interface. Mar. Geol. 78, 303-310.

Shokes, R.F., Trabant, P.K., Presley, B.J., Reid, D.R., 1977. Anoxic, hypersaline basin in the northern Gulf of Mexico. Science 196, 1443-1446.

Singer, B.S., Guillou, H., Jicha, B.R., Laj, C., Kissel, C., Beard, B.L., Johnson, C.M., 2009. 40Ar/39Ar, K-Ar and 230Th-238U dating of the Laschamp excursion: a radio isotopic tie point for ice core and climate chronologies. Earth Planet. Sci. Lett. 286, 80-88.

Sionneau, T., Bout-Roumazeilles, V., Biscaye, P.E., Van Vliet-Lanoë, B., Bory, A., 2008. Clay mineral distributions in and around the Mississippi River watershed and Northern Gulf of Mexico: sources and transport patterns. Quat. Sci. Rev. 27, 1740-1751.

Sionneau, T., Bout-Roumazeilles, V., Flower, B.P., Bory, A., Tribovillard, N., Kissel, C., Van Vliet-Lanoë, B., Montero-Serrano, J.C., 2010. Provenance of freshwater pulses in the Gulf of Mexico during the last deglaciation. Quat. Res. 74, 235-245.

Stuiver, M., Grootes, P.M., 2000. GISP2 Oxygen Isotope Ratios. Quat. Res. 53, 277-284.

Thiry, M., 2000. Paleoclimatic interpretation of clay minerals in marine deposits: an outlook from the continental origin. Earth Sci. Rev. 49, 201-221.

Tribovillard, N., Bout-Roumazeilles, V., Algeo, T., Lyons, T.W., Sionneau, T., MonteroSerrano, J.C., Riboulleau, A., Baudin, F., 2008. Paleodepositional conditions in the Orca Basin as inferred from organic matter and trace metal contents. Mar. Geol. 254, 62-72.

Van Meerbeeck, C.J., Renssen, H., Roche, D.M., 2009. How did Marine Isotope Stage 3 and Last Glacial Maximum climates differ? e perspectives from equilibrium simulations. Clim. Past 5, 33-51.

Voelker, A.H.L., Workshop Participants, 2002. Global distribution of centennial scale records for Marine Isotope Stage (MIS) 3: a database. Quat. Sci. Rev. 21, 1185-1212.

Wang, H., Hughes, R.E., Steele, J.D., Lepley, S.W., Tian, J., 2003. Correlation of climate cycles in middle Mississippi Valley loess and Greenland ice. Geology 31, 179-182.

Wang, H., Lundstrom, C.C., Zhang, Z., Grimley, D.A., Balsam, W.L., 2009. A Mid-Late Quaternary loess-paleosol record in Simmons Farm in southern Illinois, USA. Quat. Sci. Rev. 28, 93-106.

Wood, J.R., Forman, S.L., Everton, D., Pierson, J., Gomez, J., 2010. Lacustrine sediments in Porter Cave, Central Indiana, USA and possible relation to Laurentide ice sheet marginal 
positions in the middle and late Wisconsinan. Palaeogeogr. Palaeoclimatol. Palaeoecol. 98, 421-431.

Ziegler, M., Nürnberg, D., Karas, C., Tiedemann, R., Lourens, L.J., 2008. Persistent summer expansion of the Atlantic Warm Pool during glacial abrupt cold events. Nat. Geosci.. http://dx.doi.org/10.1038/ngeo277. 
Figure captions

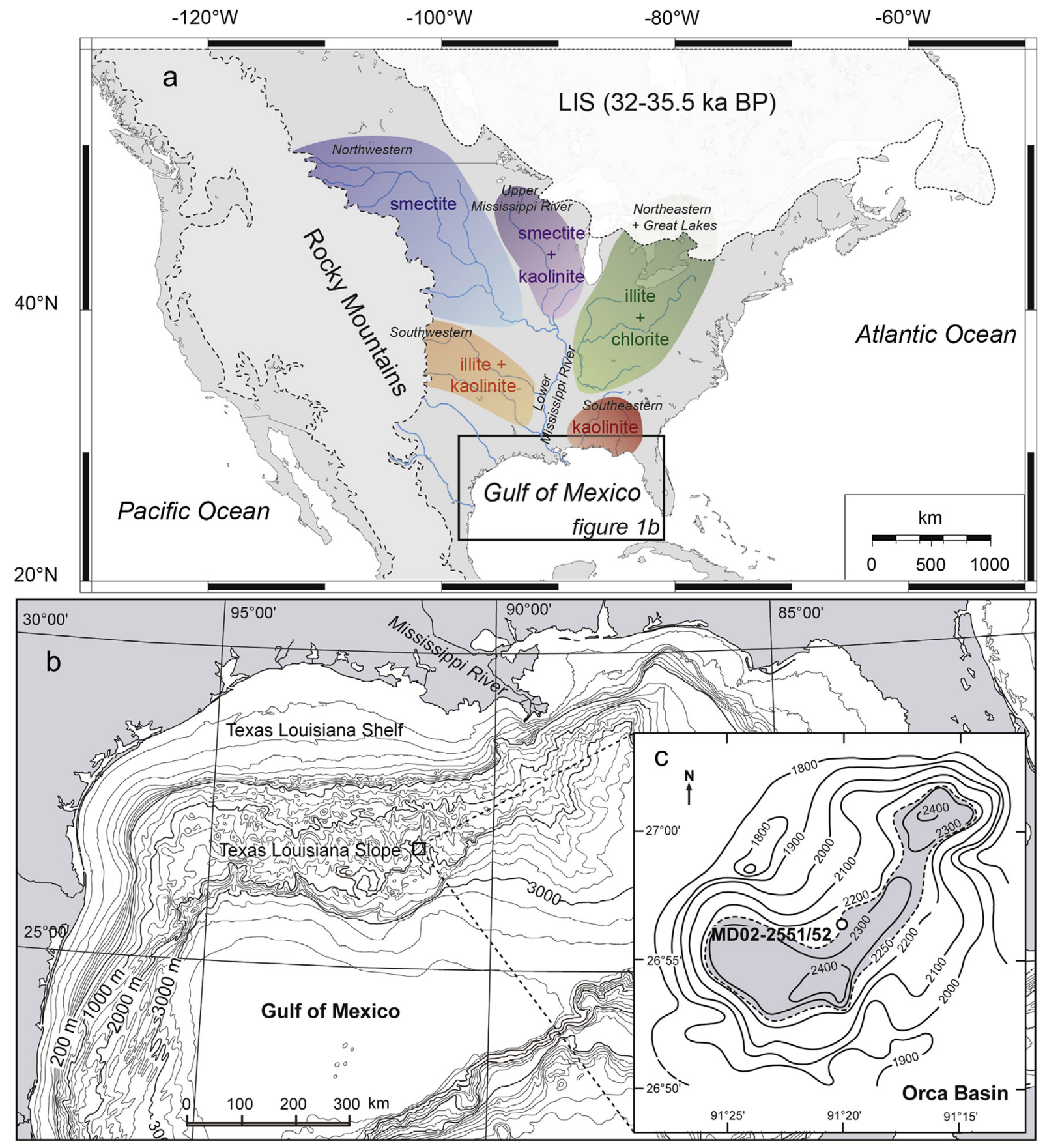

Fig. 1. Location of (a) the main mineralogical province in and around the Mississippi River watershed and limit of the Laurentide Ice Sheet (LIS) during MIS3 (Dyke et al., 2002); (b) the Orca Basin on the Louisiana continental slope; (c) the two cores reported in this study. 


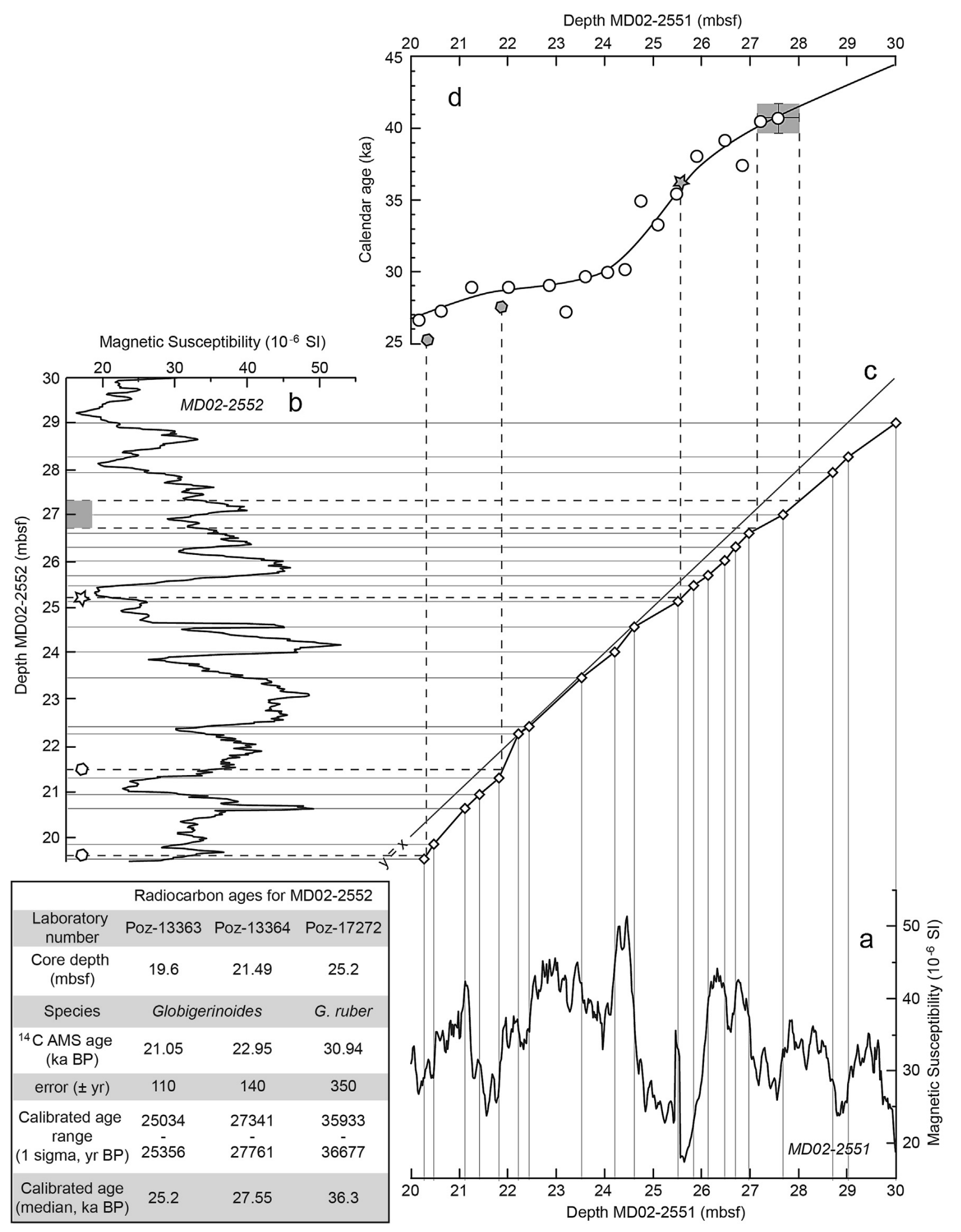

Fig. 2. Correlation between cores MD02-2551 (Hill et al., 2006) and MD02-2552 (Orca Basin) using magnetic susceptibility, table of radiocarbon ages from core MD02-2552 and extrapolated age model. (a e bottom) Magnetic susceptibility record from core MD02-2551; (b e left) magnetic susceptibility record from core MD02-2552 (gray rectangle indicates 
the position of the Laschamp geomagnetic event, white star marks the position of a 14C date from G. ruber, and hexagons indicate the position of $14 \mathrm{C}$ dates from mixed Globigerinoides); (c e middle) depth/depth relationship between the two cores (diamonds represent correlation points); and (d e top) age model (Hill et al., 2006) used in this study [circles represent MD02-2551 dates, gray star and hexagons indicate the stratigraphic position of 14C dates converted in calendar years (Fairbanks et al., 2005) and the gray rectangle indicates the stratigraphic position of the Laschamp geomagnetic event from core MD02-2552]. 


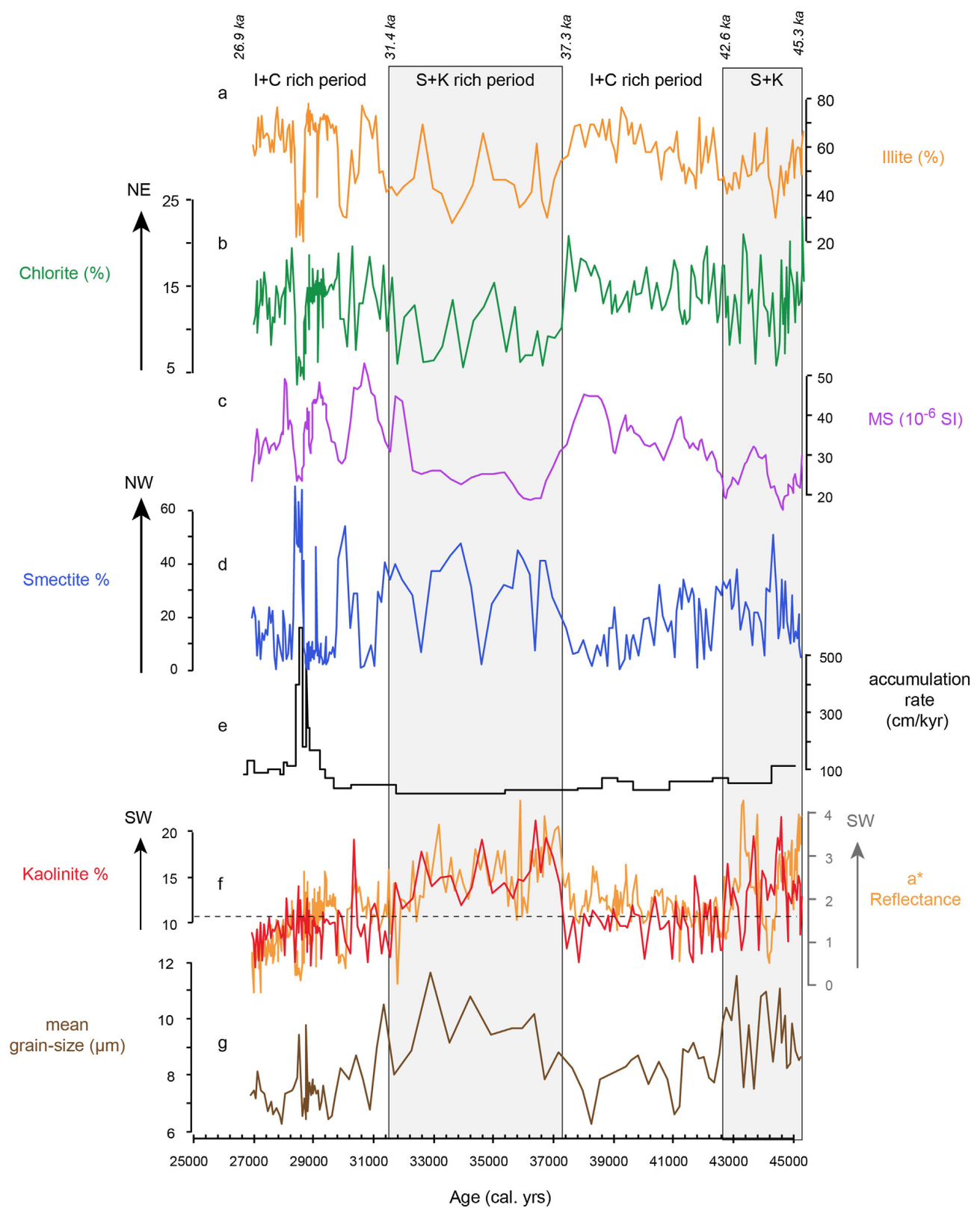

Fig. 3. Clay mineral and sedimentological records from the Orca Basin during MIS3 (26e46 ka). a: illite \%; b: chlorite \%; c: magnetic susceptibility; d: smectite \%; e: accumulation rate (cm/ka); f: kaolinite \% (red curve) and $\mathrm{a}^{*}$ reflectance parameter (orange curve); g: mean grain-size $(\mathrm{mm})$ from core MD02-2552. Limits between (I + C)rich and $(S+K)$-rich intervals are indicated by vertical black lines. S: smectite, I: illite, K: kaolinite; C: chlorite. Arrows indicate the main continental provenance of the detrital sediments (NE: Great Lakes area and northeastern part of the Mississippi River watershed; NW: Missouri River watershed; SW: southwestern Mississippi River watershed). 


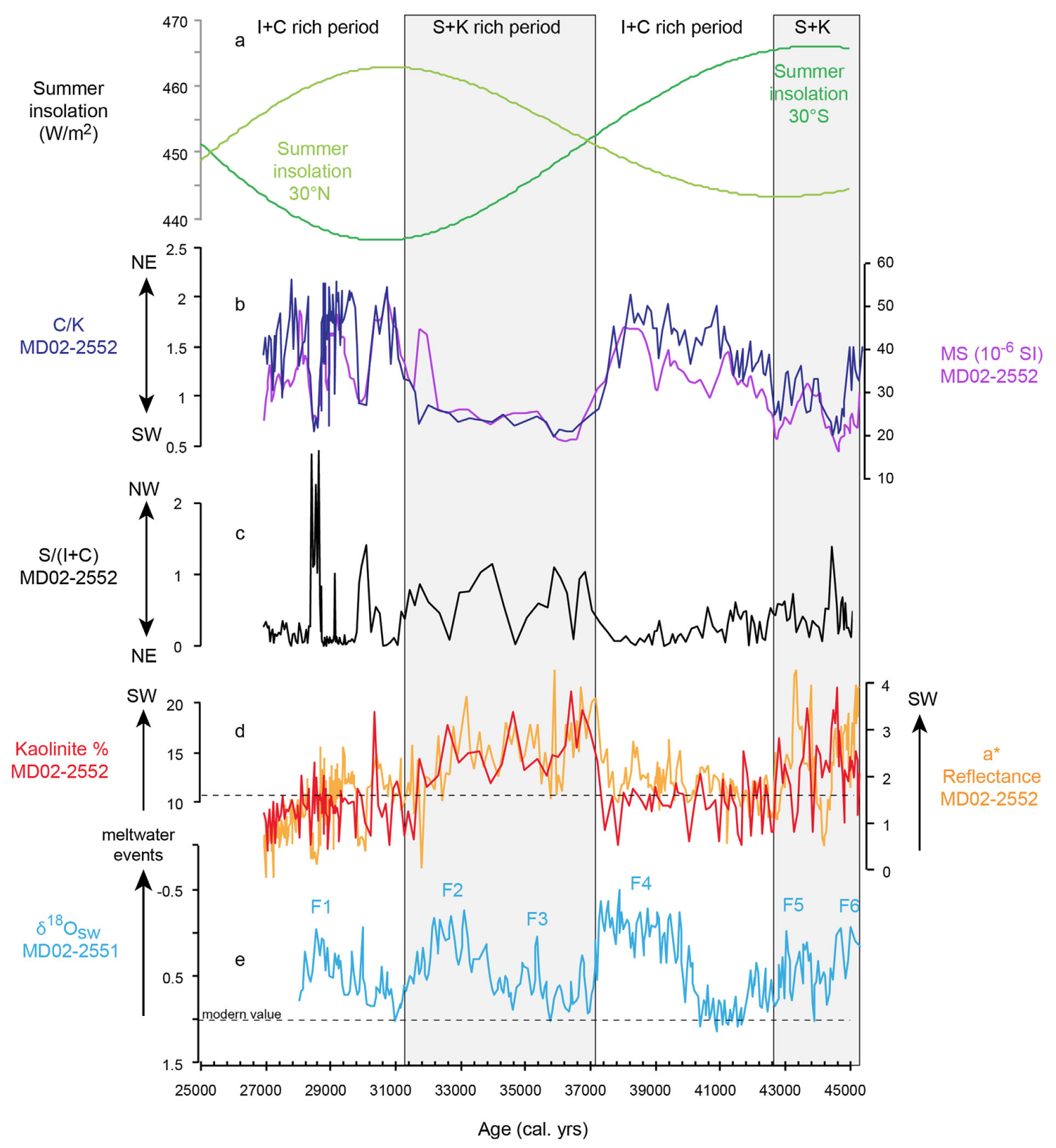

Fig. 4. Comparison between clay mineral record from core MD02-2552 and other paleoclimatic records of the Last Glacial period (26-46 ka BP). a: summer insolation at $30^{\circ} \mathrm{N}$ and $30^{\circ} \mathrm{S}$; b: chlorite to kaolinite ratio (blue) and magnetic susceptibility (purple); c: ratio between smectite and (illite + chlorite); d: kaolinite \% (red) and a* reflectance parameter (orange); e: $\delta^{18} \mathrm{O}_{\mathrm{SW}}$ record (MD02-2551) F1 to F6 $1 / 4$ meltwater floods (Hill et al., 2006; Flower et al., 2011). Limits between ( + C)-rich and (S + K)-rich intervals are indicated by vertical black lines. Arrows indicate the main continental provenance of the detrital sediments (NE: Great Lakes area and northeastern part of the Mississippi River watershed; NW: Missouri River watershed; SW: southwestern Mississippi River watershed). 


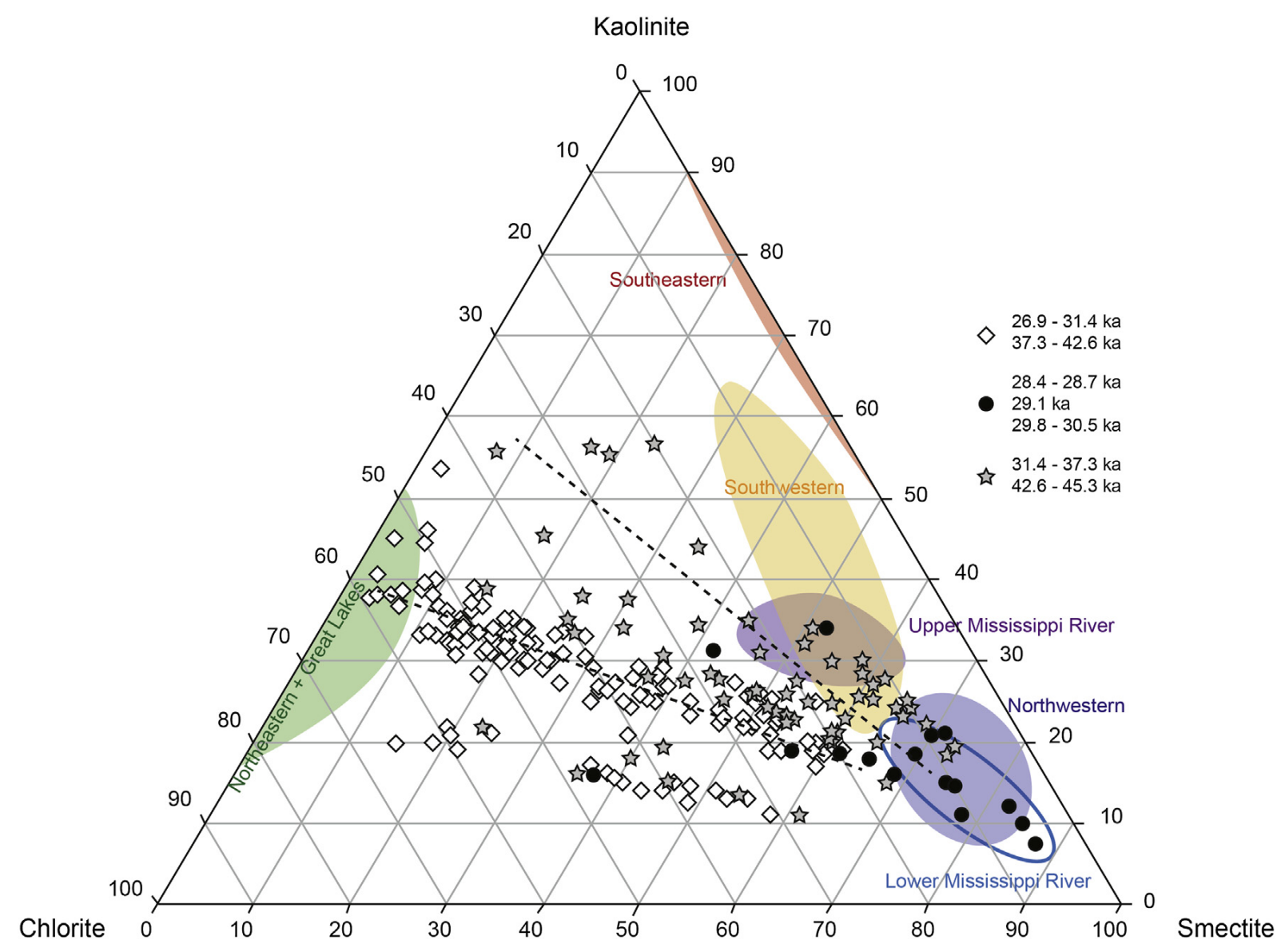

Fig. 5. Distribution of the samples from the (I ? C)-rich (with diamonds), (K ? S)-rich (gray stars) intervals and short smectite-rich episodes (black circles) in a ternary diagram. The main North American mineralogical provinces data are reported in this diagram (Sionneau et al., 2008). 


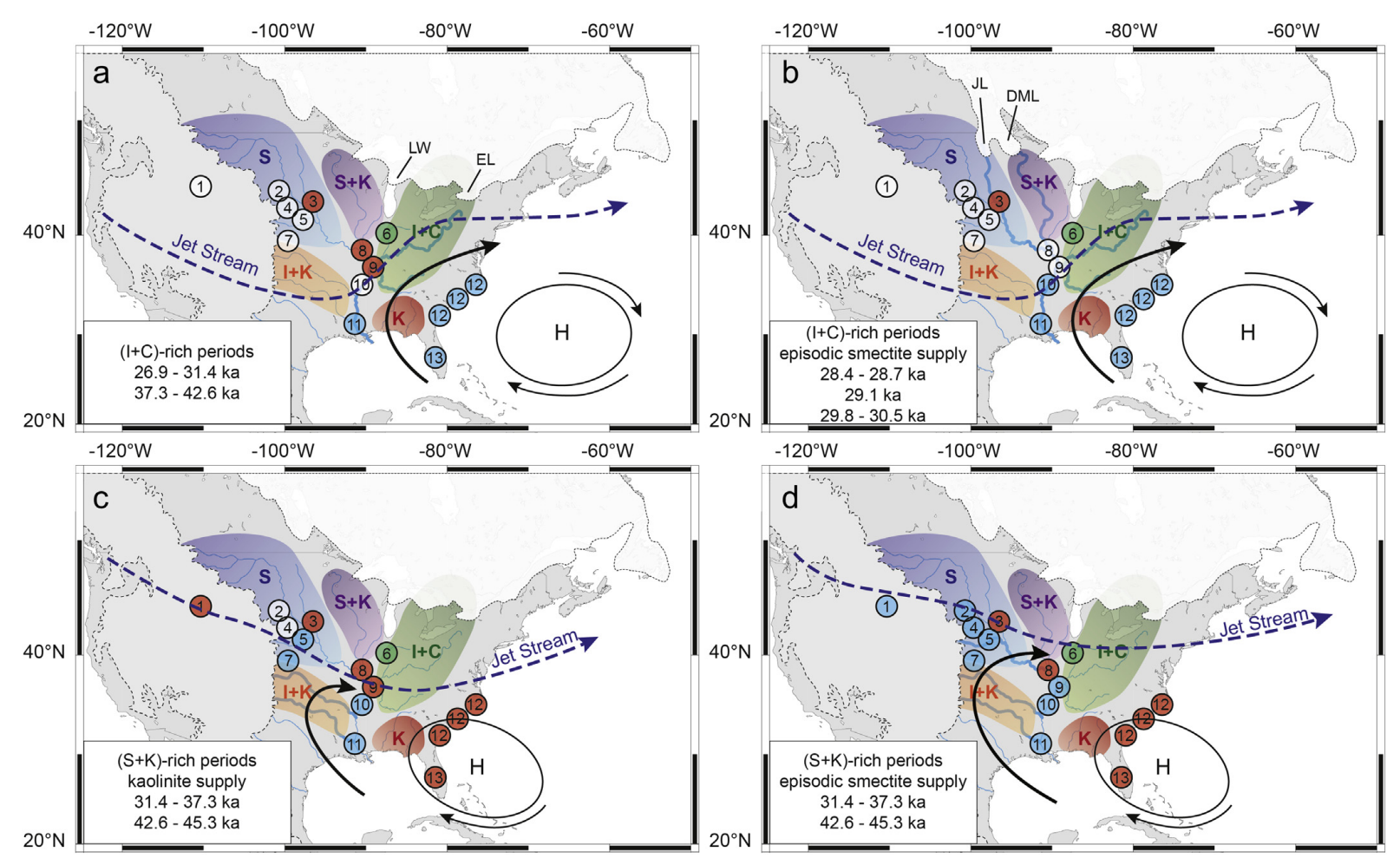

Fig. 6. Reconstruction of atmospheric circulation pattern over North America. a: $(I+C)$ rich intervals; b: smectite-rich events occurring during $(I+C)$-rich intervals; $c$ : $(K+S)$ rich intervals; d: specific smectite supply during $(\mathrm{K}+\mathrm{S})$-rich intervals. The main mineralogical provinces of North America are indicated (Sionneau et al., 2008) as well as the estimated extent of the LIS between 32 and 35.5 ka BP (Dyke et al., 2002; Van Meerbeeck et al., 2009). The moisture export from the Atlantic Warm Pool and the GOM is indicated by black arrows; the estimated position of the Polar Jet Stream by dotted blue arrows (adapted from Kutzbach and Wright, 1985; Van Meerbeeck et al., 2009). H: Bermuda High, LW: Lake Wisconsin glacial lobe; EL: Erie Lobe, JL: James lobe; DML: Des Moines lobe. Numbered circles refer to study sites used in the discussion (1: Pierce et al., 2011; 2: Jacobs et al., 2007; 3: Forman et al., 1992; 4: Johnson et al., 2007; 5: Baker et al., 2009; 6:Wood et al., 2010; 7: Fredlund, 1995; 8: Forman et al., 1992; 9:Wang et al., 2009; 10: Rittenour et al., 2005; 11: Rittenour et al., 2005; 12: Leigh et al., 2004; and 13: Grimm et al., 2006; Donders et al., 2011). White circle: no data; blue circle: humid conditions; red circle: arid conditions; green circle: presence of glacial activity. 
Table 1

Composition of the four main clay-mineral provinces of North America, the upper and the lower Mississippi River watersheds (for more details see Sionneau et al., 2008). S: smectite, I: illite, K: kaolinite, C: chlorite.

\begin{tabular}{llllc}
\hline Mineralogical province & $\mathrm{S}(\mathscr{*})$ & $\mathrm{I}(\boldsymbol{\%})$ & $\mathrm{K}(\%)$ & $\mathrm{C}(\%)$ \\
\hline Upper Mississippi River & 43 & 23 & 25 & 9 \\
Northwestern province & 55 & 27 & 13 & 5 \\
Northeastem and Great & 5 & 45 & 18 & 32 \\
$\quad$ Lakes province & & & & \\
Lower Mississippi River & 57 & 25 & 10 & 8 \\
Southeastem province & 32 & 10 & 58 & 0 \\
Southwestem province & 37 & 34 & 23 & 6 \\
\hline
\end{tabular}

Table 2

Average composition of the four time intervals observed on the clay mineralogical record (S: smectite, I: illite, K: kaolinite, C: chlorite).

\begin{tabular}{lllcl}
\hline Time interval & $\mathrm{S}(\%)$ & $\mathrm{I}(\%)$ & $\mathrm{K}(\%)$ & $\mathrm{C}\left(\%_{)}\right)$ \\
\hline $29.6-31.4 \mathrm{ka}$ & 15 & 63 & 9 & 13 \\
$31.4-37.3 \mathrm{ka}$ & 32 & 44 & 14 & 10 \\
$37.3-42.6 \mathrm{ka}$ & 16 & 60 & 10 & 14 \\
$42.6-45.3 \mathrm{ka}$ & 23 & 50 & 14 & 13 \\
\hline
\end{tabular}

